5. Toh C.-K., Heng D., Ong Y.-K. và cộng sự. (2005). Validation of a new prognostic index score for disseminated nasopharyngeal carcinoma. $\mathrm{Br}$ ] Cancer, 92(8), 1382-1387.

6. Zhang L., Huang Y., Hong S. và cộng sự. (2016). Gemcitabine plus cisplatin versus fluorouracil plus cisplatin in recurrent or metastatic nasopharyngeal carcinoma: a multicentre, randomised, open-label, phase 3 trial. The Lancet, 388(10054), 1883-1892.

7. Eisenhauer E.A., Therasse P., Bogaerts J. và cộng sự. (2009). New response evaluation criteria in solid tumours: Revised RECIST guideline (version 1.1). European Journal of Cancer, 45(2), 228-247.

8. Jiang Y., Wei Y., Luo F. và cộng sự. (2005). Gemcitabine and Cisplatin in Advanced Nasopharyngeal Carcinoma: A Pilot Study. Cancer Investigation, 23(2), 123-128.

9. Hsieh J.C.-H., Hsu C.-L., Ng S.-H. và công sư. (2015). Gemcitabine plus cisplatin for patients with recurrent or metastatic nasopharyngeal carcinoma in Taiwan: a multicenter prospective Phase II trial. Jpn J Clin Oncol, 45(9), 819-827.

\title{
ĐĂC ĐIỂM LÂM SÀNG VÀ HÌNH ẢNH CộNG HƯởNG TỪ CỦA BẾNH VIÊM THI THẦN KINH Ở TRẺ EM
}

\section{TÓM TẮT}

Mục tiêu: Mô tả đặc điểm lâm sàng và hình ảnh công hưởng từ của bênh viêm thi thân kinh ở trẻ em. Phương pháp nghiên cứu: Đây là nghiên cứu mô tả cắt ngang, gồm 47 bênh nhân được chẩn đoán và điều trị bệnh viêm thị thần kinh tại Trung tâm thần kinh - Bệnh viện Nhi Trung Ương, trong thời gian 5 năm từ tháng $1 / 6 / 2016$ đến 31/5/2021. Kết quả: 47 bệnh nhân thỏa mãn các tiêu chuẩn lựa chọn, với 83 mắt bị tổn thương. Tuổi trung bình lúc khởi phát bênh là $8,52 \pm 3,1$ tuối. Có 27 bệnh nhân nam và 20 bệnh nhân nữ, tî lệ nam/ nữ là 1,35/ 1. Tại thời điểm khởi phát, có 11 bệnh nhân $(23,4 \%)$ tổn thương một bên mắt, 36 bệnh nhân $(76,6 \%)$ tổn thương 2 bên mắt. Tất cả bênh nhân vào viện vì giảm hoăc mất thị lực, trong đó 22 bệnh nhân $(46,8 \%)$ có tiền sử ho/ sốt trong thời gian 1 tháng trước khởi bệnh. 68 mắt $(81,9 \%)$ có thi lức giảm năng $<1 / 10$ khi vào viên, 48 mắt $(57,8 \%)$ có phù gai thị trên soi đáy mắt. $9 / 47$ bênh nhân $(19,1 \%)$ có các đợt tái phát viêm thị thần kinh. Cộng hưởng từ (CHT) sọ não - ổ mắt cho thấy 10 bênh nhân có tổn thương viêm thi thần kinh hâu nhãn cầu điển hình. Bên cạnh đó, 4 bênh nhân khác có tổn thương chất trắng/ chất xám từ lần đâu khởi bệnh, và 1 bênh nhân trong nhóm này đã tái phát đợt viềm thị thần kinh thứ 2 . Kết luận: Viêm thị thần kinh ở trẻ em có thị lực giảm nặng khi khởi bệnh. CHT sọ não - ổ mắt đóng vai trò quan trọng trong chẩn đoán và tiên lượng diễn biến bệnh. - ổ mắt

Tư khóa: viêm thị thần kinh ở trẻ em, CHT sọ não

\section{SUMMARY \\ CLINICAL AND MAGNETIC RESONANCE IMAGING FEATURES OF PEDIATRIC OPTIC NEURITIS}

\footnotetext{
* Trường Đại hoc Y Hà Nội

** Bênh viện Nhi Trung Ương

Chịu trách nhiệm chính: Đào Thị Việt Hường

Email: dothanhhuong@hmu.edu.vn

Ngày nhận bài: 28.9.2021

Ngày phản biên khoa hoc: 29.9.2021

Ngày duyệt bài: 4.10 .2021
}

Objectives: Clinical and magnetic resonance imaging features of pediatric optic neuritis. Method: This is a cross-sectional study including 47 patients with optic neuritis in the Neurology Centre of National Children's Hospital, for a period of 5 years from June, $1^{\text {th }}, 2016$ to May, 31 ${ }^{\text {th }}, 2021$. Results: 47 patients with 83 affected eyes. Mean age of onset was 8,52 \pm 3,1 . There were 27 male patients and 20 female patients. Male/ female ratio was 1,35/1. 11 patients $(23,4 \%)$ had unilateral involvement, and 36 patients $(76,6 \%)$ had bilateral involvement. All patients admitted to the hospital because of reduced or lost vision, 22 patients $(46,8 \%)$ had viral prodrome during one month before the onset of disease. 68 eyes $(81,9 \%)$ had a visual acuity lower of $1 / 10$ at the time of initial presentation, 48 eyes $(44,9 \%)$ had optic disc edema. $9 / 47$ patients $(19,1 \%)$ had relapse optic neuritis. Magnetic resonance imaging (MRI) brain orbital showed 10 patients with typical retrobulbar neuritis. In addition, 4 other patients had white/ gray matter lesions from the initial onset, and one patient in this group had a second episode of relapse optic neuritis. Conclusion: Pediatric optic neuritis had poor vision at onset. MRI brain - obital plays an important role in diagnosis and prognosis of disease progression. obital.

Key words: pediatric optic neuritis, MRI brain -

\section{I. ĐẶT VẤN ĐỀ}

Viêm thị thân kinh ở trẻ em là bệnh lý hiếm gặp, thuộc nhóm bệnh hủy myelin mắc phải của hệ thân kinh trung ương, đăc trưng bởi mất thị lực cấp tính hoặc bán cấp, tổn thương thị trường và thị lực màu sắc, tổn thương phản xạ đồng tử hướng tâm, tăng tín hiệu dây thân kinh thị trên phim cộng hưởng từ và giảm tốc độ dẫn truyên trên điện thế gợi kích thích thị giác. Bệnh có thể biểu hiện như một bệnh đơn độc, thường sau một đợt nhiễm virus hoặc tiêm vắc xin, hoặc có thể là biểu hiện của nhóm bệnh hủy myelin tiềm ẩn, như xơ cứng rải rác, viêm tủy thị thân kinh hay viêm não tủy lan tỏa cấp tính [1], [2]. 
Hiện nay ở Việt Nam đã có những nghiên cứu về viêm thị thần kinh ở người lớn, nhưng chưa có các nghiên cứu đầy đủ về bệnh lý này ở trẻ em về đặc điểm lâm sàng và hình ảnh cộng hưởng từ. Vì vậy, chúng tôi tiến hành nghiên cứu "Đặc điểm lâm sàng và hình ảnh cộng hưởng từ của bênh viêm thị thần kinh ở trẻ em", với mục đích hỗ trợ cho chẩn đoán sớm, nhằm nâng cao chất lượng điều trị, và góp phần vào cải thiện tiên lượng lâu dài cho bệnh nhân.

\section{II. ĐỐI TƯƠNGG VÀ PHƯƠNG PHÁP NGHIÊN CỨU}

2.1. Đối tượng nghiên cứu. Gồm các bệnh nhân nhi từ 0 - 17 tuổi, được chẩn đoán và điều trị viêm thị thần kinh tại Trung tâm Thần kinh Bệnh viện Nhi Trung ương.

Tiêu chuẩn lựa chọn:

- Bệnh nhân được chẩn đoán xác định viêm thị thần kinh theo tiêu chuẩn sau [3] [4]:

。 Giảm/ mất thị lực cấp tính hoặc bán cấp, và không có bằng chứng về các nguyên nhân khác như: chuyển hóa, ngộ độc, nguyên nhân mạch máu hay chèn ép.

o Kèm theo ít nhất 1 dấu hiệu sau: tổn thương phản xạ đồng tử hướng tâm, tổn thương thị trường hoặc ám điểm, rối loạn thị lực màu sắc, phù gai thị hoặc điện thế gợi kích thích thị giác bất thường.

- Được chụp phim cộng hưởng từ sọ não - ổ mắt.

Tiêu chuẩn loại trừ: hồ sơ bệnh án không đầy đủ thông tin, gia đình bệnh nhân không đồng ý tham gia nghiên cứu.

2.2. Phương pháp nghiên cứu. Nghiên cứu mô tả cắt ngang, chọn mẩu thuận tiện trong thời gian 5 năm, từ $1 / 6 / 2016$ đến 31/5/2021.

Số liệu được thu thập theo mẫu bệnh án nghiên cứu, xử lý số liệu theo các phương pháp thống kê với phần mềm SPSS 20.0, sử dụng các test thống kê phù hợp. Khi so sánh, mức khác biệt được coi là có ý nghĩa thống kê khi p < 0,05.

\section{KẾT QUẢ NGHIÊN CỨU}

Có 47 bệnh nhân thỏa mãn các tiêu chuẩn lựa chọn trong thời gian nghiên cứu với kết quả như sau:

3.1. Đặc điểm lâm sàng của bệnh nhân viêm thị thân kinh

3.1.1. Phân bố tuổi. 47 bệnh nhân trong nghiên cứu, tuổi trung bình lúc khởi bệnh là 8,52 $\pm 3,1$ tuổi, bệnh nhân nhỏ nhất là 30 tháng, lớn nhất là 15 tuổi.

\subsubsection{Phân bố giới tính}

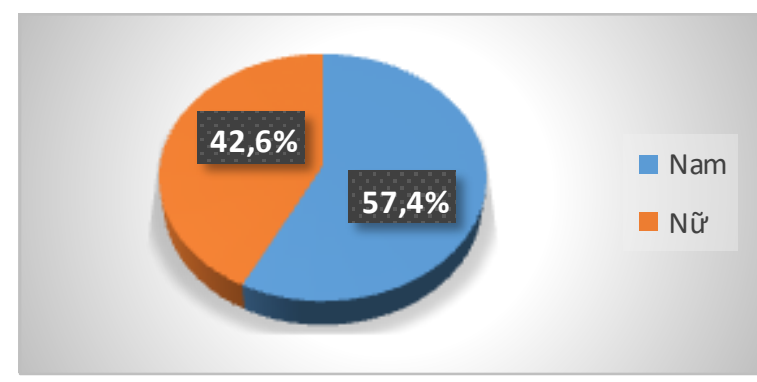

Biểu đồ 1: Phân bố giới tính

Nhận xét: Trong 47 bệnh nhân nghiên cứu, có 27 bệnh nhân nam (chiếm 57,4\%), 20 bệnh nhân nữ (chiếm 42,6\%). Tỉ lệ nam/ nữ = 1,35/ 1 .

3.1.3. Triệu chứng lẩm sàng của bệnh nhân khi nhập viện

Bảng 1: Triệu chứng lâm sàng của bệnh nhân khi nhập viện

\begin{tabular}{|c|c|c|}
\hline & $\begin{array}{c}\text { Số lượng } \\
\text { BN }\end{array}$ & $\begin{array}{c}\text { Tỉ lệ } \\
(\%)\end{array}$ \\
\hline Giảm/ mất thị lực & 47 & 100 \\
\hline Đau đâu & 9 & 19,1 \\
\hline Đau hốc mắt & 9 & 19,1 \\
\hline $\begin{array}{c}\text { Đau hốc mắt tăng khi cứ } \\
\text { động mắt }\end{array}$ & 9 & 19,1 \\
\hline $\begin{array}{c}\text { Tiền sứ sốt/ ho/đau họng } \\
\text { trong } 1 \text { tháng trước khởi bệnh }\end{array}$ & 22 & 46,8 \\
\hline $\begin{array}{c}\text { Tiên sứ tiêm chủng trong 1 } \\
\text { tháng trước khởi bệnh }\end{array}$ & 0 & 0 \\
\hline Tống cộng & $\mathbf{4 7}$ & $\mathbf{1 0 0}$ \\
\hline
\end{tabular}

Nhân xét: $100 \%$ bệnh nhân vào viện vì mất/ giảm thị lực đột ngột hoặc tăng dần. 46,8\% trường hợp có sốt/ ho/ đau họng trong vòng 1 tháng trước khởi bệnh. Đau đầu gặp ở 9 bệnh nhân $(19,1 \%)$, có $19,1 \%$ có đau hốc mắt và đau tăng khi vận động nhãn câu.

\subsubsection{Số măt tổn thương}

Bảng 2: Số mát tổn thương lúc nhập viện

\begin{tabular}{|c|c|c|c|}
\hline & & $\begin{array}{c}\text { Số bệ̂nh } \\
\text { nhânn }\end{array}$ & $\begin{array}{c}\text { Tỉ lệ } \\
\text { (\%) }\end{array}$ \\
\hline $\begin{array}{c}\text { Số mắt tốn } \\
\text { thương }\end{array}$ & Hai mắt & 36 & 76,6 \\
\hline Tống & & 11 & 23,4 \\
\hline
\end{tabular}

Nhận xét: Trong 47 bệnh nhân nghiên cứu, có $76,6 \%$ bệnh nhân tổn thương 2 mắt, 23,4\% bệnh nhân tổn thương 1 mắt.

3.1.5. Đặc điểm tổn thương đáy mắt và thị lực lúc nhập viện. Nghiên cứu của chúng tôi gổm 47 bệnh nhân với 83 mắt bị tổn thương với đặc điểm tổn thương như sau:

Bảng 3: Đặc điểm tổn thương đáy mắt và thị lực lúc nhập viện

\begin{tabular}{|l|l|l|l|}
\hline & $\begin{array}{c}\text { Số măt tốn } \\
\text { thương }\end{array}$ & $\begin{array}{c}\text { Tỉ lệ } \\
(\%)\end{array}$ \\
\hline
\end{tabular}




\begin{tabular}{|c|c|c|c|}
\hline \multirow{4}{*}{$\begin{array}{c}\text { Thị lực lúc } \\
\text { nhập viện }\end{array}$} & $\begin{array}{c}<1 / 10 \\
<3 / 10\end{array}$ & 68 & 81,9 \\
\cline { 2 - 4 } & $\begin{array}{c}\geq 3 / 10 \\
\text { Tống }\end{array}$ & 9,6 \\
\cline { 2 - 4 } & Phù gai & $\mathbf{8 3}$ & $\mathbf{1 0 0}$ \\
\hline \multirow{4}{*}{$\begin{array}{c}\text { Đáy mắt lúc } \\
\text { nhập viện }\end{array}$} & $\begin{array}{c}\text { Gai thị nhạt } \\
\text { màu }\end{array}$ & 3 & 57,8 \\
\cline { 2 - 4 } & Teo gai & 1 & 3,6 \\
\cline { 2 - 4 } & Bình thường & 31 & 37,4 \\
\cline { 2 - 4 } & Tống & $\mathbf{8 3}$ & $\mathbf{1 0 0}$ \\
\hline
\end{tabular}

Nhận xét: Có 68 mắt $(81,9 \%)$ bị giảm thị lực nặng <1/10; có 8 mắt $(9,6 \%)$ bị giảm thị lực trung bình $1 / 10-3 / 10$, và có 7 mắt $(8,5 \%)$ bị giảm thị lực nhẹ $\geq 3 / 10$ tại thời điểm nhập viện. Khi soi đáy mắt phát hiện 48 mắt $(57,8 \%)$ bị phù gai thị, 3 mắt $(3,6 \%)$ có gai thị bạc màu, 1 mắt $(1,2 \%)$ bi teo gai.

3.1.6. Đắc điểm tổn thương phản xạ đồng tử hưởng tâm (RAPD)

Bảng 4: Đặc điểm tổn thương phản xạ đồng tứ hướng tâm $(n=16)$

\begin{tabular}{|c|c|c|}
\hline & Số lượng bệnh nhân & Tỉ lệ (\%) \\
\hline RAPD (+) & 12 & 75 \\
\hline RAPD (-) & 4 & 25 \\
\hline Tống & $\mathbf{1 6}$ & $\mathbf{1 0 0}$ \\
\hline
\end{tabular}

Nhận xét: Trong 16 bệnh nhân được khám phản xạ hướng tâm (RAPD), có 12 bệnh nhân (75\%) có RAPD $(+)$, 4 bệnh nhân $(25 \%)$ có RAPD (-).

3.1.7. Tỉ lệ tái phát viêm thị thân kinh. Trong thời gian nghiên cứu, chúng tôi thấy có $9 /$
47 bệnh nhân $(19,1 \%)$ tái phát các đợt viêm thị thần kinh, trong đó 6 bệnh nhân tái phát 2 lần, 2 bệnh nhân tái phát 3 lần, 1 bệnh nhân tái phát 4 lần, với thời gian trung bình giữa các đợt tái phát là 8,7 tháng (2 đợt tái phát gần nhất là 39 ngày, 2 đợt xa nhất là 36 tháng).

3.2. Đăcc điểm cộng hưởng từ so não - ổ mắt của bệnh nhân viêm thị thần kinh. Chúng tôi phẩn tích hình ảnh $\mathrm{CHT}$ sọ não - ổ mắt của 47 bệnh nhân cho kết quả như sau.

3.2.1. Đặc điểm tổn thương thân kinh thị giác trên phim cộng hưởng từ. Trong 21 bệnh nhân được chẩn đoán viêm thị thần kinh hậu nhãn cầu, 10 bệnh nhân có hình ảnh điển hình của tổn thương viêm trên phim chụp. Các tổn thương được mô tả bao gồm: dây thần kinh thị giác tăng kích thước, tăng tín hiệu trên các chuối xung T2W, FLAIR, CIS, và tăng ngấm thuốc sau tiêm thuốc đối quang từ.

Tất cả 10 bệnh nhân này đều không có tổn thương chất trắng/ chất xám tại lần chụp đầu tiên. Tuy nhiên, có $4 / 10$ bệnh nhân trong nhóm này đã có các đợt tái phát viêm thị thần kinh trong thời gian theo dõi ( 2 bệnh nhân tái phát 2 lần, 2 bệnh nhân tái phát 3 lần). CHT ở các lần tái phát chưa phát hiện tổn thương khác ngoài dây thần kinh thị giác.

\subsection{2. Đặc điểm tổn thương não trên} phim cộng hưởng từ

Trong 47 bệnh nhân nghiên cứu, có 4 bệnh nhân $(8,5 \%)$ có tổn thương não tại lần chụp CHT đầu tiên.

\begin{tabular}{|c|c|c|c|}
\hline & Giới tính & Tuối khởi phát & Tốn thương trên CHT \\
\hline BN 1 & Nữ & 49 tháng & $\begin{array}{l}\text { Rải rác tăng tín hiệu nhu mô não chất trắng và nhân } \\
\text { xám } 2 \text { bán cầu đại não. }\end{array}$ \\
\hline BN 2 & Nữ & 8 tuối & Tốn thương đa ố chất trắng 2 bán cầu đại não. \\
\hline BN 3 & Nam & 11 tuổi & $\begin{array}{l}\text { Rải rác tăng tín hiêu nhu mô não chất trắng thùy trán và } \\
\text { chẩm trái trên } T 2 W \text {, FLAIR }\end{array}$ \\
\hline *BN 4 & Nam & 9 tuổi & $\begin{array}{l}\text { Ô tăng tín hiệu cánh tay sau bao trong bên phải trên } \\
\qquad \text { T2W, FLAIR }\end{array}$ \\
\hline
\end{tabular}

*BN 4: Tái phát đợt viêm thị thần kinh thứ 2 sau 39 ngày.

Nhận xét: Trong 4 bênh nhân có tổn thương não trển phim $\mathrm{CHT}$ lúc khởi bênh: 2 bệnh nhân có tổn thương chất trắng đa ổ bán câu đại não (BN 2 và $B N 3), 1$ bệnh nhân tổn thương cả chất trắng và chất xám ( $\mathrm{BN} 1)$, và 1 bệnh nhân tổn thương chất xám đớn thuân (BN 4). BN 4 đã tái phát 1 đợt viêm thị thần kinh thứ 2 sau 39 ngày kể từ đợt 1 , tuy nhiên phim $\mathrm{CHT}$ lần 2 chưa thây bất thường.

\section{BÀN LUÂ̂N}

4.1 Đặc điểm lâm sàng của bệnh viêm thị thần kinh. Biểu đồ 1 cho thấy tỉ lệ nam/ nữ $=1,35 / 1$. Trong nhóm bệnh nhân nghiên cứu của chúng tôi, viêm thị thần kinh gặp nhiều ở trẻ nam hơn nữ. Kết quả này khác biệt với nghiên cứu của tác giả Lê Thị Doan (2013) cho tỉ lệ nam/ nữ là 1/ 1,5 [5], của tác giả Selvakumar Ambika (2018) cho tî lệ nam/ nữ là 1/ 1,2 [6], và tác giả Absoud (2011) cho tỉ lệ nam/nữ là $1 /$ $1,8[7]$. Đa số các nghiên cứu trên thế giới về viêm thị thần kinh cho kết quả bệnh gặp ở nữ nhiều hớn nam. Tuy nhiên chưa có nguyền nhân 
cụ thể nào được đưa ra để lý giải cho điều này. Sự khác biệt trong kết quả của chúng tôi có thể do sự mất cân bằng giới tính ở Việt Nam hiên nay, hoặc do cõ̃ mẩu nhỏ hoặc có thể là diển biến tự nhiên của bệnh tại nước ta.

Bảng 1 thể hiện các triệu chứng lâm sàng ghi nhận được khi vào viện. Tất cả 47 bênh nhân đều giảm/ mất thị lực ở các mức độ khác nhau, các triệu chứng khác như đau đầu gặp ở 9 bệnh nhân $(19,1 \%)$, đau hốc mắt, đau tăng lên khi vận động nhãn cầu cũng được ghi nhận ở số bềnh nhân tương tự. Tiền sử nhiểm virus không đặc hiệu như sốt/ ho/ đau họng trong vòng 1 tháng trước khi khởi bệnh có ở 22 bệnh nhân $(46,8 \%)$, cao hơn so với tỉ lệ $16,7 \%$ của tác giả Lê Thị Doan [5]. Điều này có thể giải thích được do viêm thị thần kinh là bệnh qua trung gian miễn dịch, thúc đẩy sau một đợt nhiễm virus hoặc tiêm vắc xin. Nghiên cứu của chúng tôi tâp trung vào cơ chế tự miễn dịch của bệnh, nển tiền sử nhiễm virus trước khởi bệnh đã được chú ý khai thác hơn trong quá trình thăm khám. Tiền sử tiêm chủng trước khởi bệnh không ghi nhận trên bệnh nhân nào, có thể giải thích do lứa tuổi bệnh nhân của chúng tôi (trung bình $8,52 \pm 3,1$ ) đã vượt qua tuổi chương trình tiêm chủng mở rộng ở nước ta.

Qua bảng 2, chúng tôi nhận thấy viêm thị thần kinh 2 bên nhiều gấp 3 lần viêm thị thần kinh 1 bên (tỉ lệ tương ứng là 76,6 \% và 23,4\%), kết quả này tương đồng với tác giả Somjit Sri Udamkajorn tại Thái Lan cho tỉ lệ viêm thị thần kinh 2 bên là $74,2 \%$ [8], và tỉ lệ này là $62,5 \%$ theo Lê Thị Doan [5]. Như vậy, viêm thị thần kinh ở trẻ em hay gặp ở 2 bên hơn 1 bên.

Bảng 3 cho thây tại thời điểm vào viện, phần lớn bệnh nhân giảm thị lực ở mức nặng $<1 / 10$ (68/83 mắt tổn thương, chiếm $81,9 \%)$. Tỉ lệ này cũng được Wilejto và cộng sự báo cáo ở $67 \%$ bệnh nhẩn [3]. Kết quả soi đáy mắt cho thây: 48 mắt $(57,3 \%)$ bi phù gai thi, 3 mắt có gai thi bạc màu, và 1 mắt bị teo gai. Như vậy, phù gai là dấu hiệu thường gặp ở bệnh nhân viêm thị thần kinh. Tỉ lệ phù gai cũng được báo cáo với kết quả tương tự trong nghiên cứu của 2 tác giả Ambika và Somjit Sri - Udamkajorn (tỉ lệ lần lượt là $50,4 \%$ và $54,8 \%$ số mắt tổn thương) [6] [8].

Trong nghiên cứu của chúng tôi, có 16 bệnh nhân được khám phản xạ đồng tử hướng tẩm, trong đó có $12 / 16$ bệnh nhân có RAPD (+) (bảng 4). RAPD (+) thể hiện tổn thương trên đường dần truyền thần kinh thị giác và rất có giá trị trong chẩn đoán, tuy nhiên chỉ được ghi nhân ở số ít bệnh nhân. Điêu này có thể giải thích do một số bệnh nhân trong nhóm nghiên cứu lấy số liệu hồi cứu chưa được khám phản xạ này. Bên cạnh đó, RAPD sẽ được ghi nhận rõ ràng hơn khi tổn thương mắt 1 bên, không rõ ràng khi tổn thương mắt 2 bên, mà nhóm bệnh nhân tổn thương 2 mắt lại chiếm tỉ lệ lớn $(76,6 \%)$ trong nghiên cứu này.

4.2 Đăcc điểm cộng hưởng từ so não - ổ mắt của bệnh viêm thị thân kinh. Tất cả 47 bệnh nhân được chụp phim CHT sọ não - ổ mắt, nhằm mục đích xác định tổn thương thị thần kinh hậu nhãn cầu, đồng thời xác định các tổn thương não khác kèm theo (như tổn thương chất trắng, chất xám). 10 bệnh nhân có tổn thương thị thần kinh của chúng tôi đều có hình ảnh điển hình của tình trạng viêm, bao gồm thị thần kinh tăng kích thước, tăng tín hiệu trên các chuỗi xung $T 2$, FLAIR, và tăng ngấm thuốc sau tiêm đối quang từ [9]. Có 4/10 trường hợp biểu hiện những đợt viêm thị thân kinh tái phát. Dù tại các lần tái phát, $\mathrm{CHT}$ được ghi nhận nhu mồ não bình thường, nhưng chúng tôi cần thêm thời gian theo dõi, bởi đã có những nghiên cứu kết luận tổn thương chiều dài dây thần kinh thị có liên quan đến sự xuất hiện tự kháng thể kháng aquaporin-4 (AQP4-IgG) và myelin oligodendrocyte (MOG-IgG) trong viêm tủy thị thần kinh và xơ cứng rải rác [9]. Chúng tôi đã làm các xét nghiệm kháng thể này và sẽ đưa ra kết quả ở bài báo tiếp theo.

Kết quả ở bảng 5 , chúng tôi mô tả 4 bệnh nhân có tổn thương não chất trắng/chất xám tại lần đầu khởi phát viêm thị thần kinh. Trong đó đã có 1 bệnh nhân tái phát đợt bệnh thứ 2 sau 39 ngày. Tuy nhiên, để đưa ra chẩn đoán cuối cùng về rối loạn hủy myelin của bệnh nhân, chúng tôi cũng cần thêm thời gian theo dõi vế mặt lâm sàng, có hay không các đợt tái phát hủy myelin khác, cũng như theo dõi về tiến triển các tổn thương theo thời gian và không gian trên phim $\mathrm{CHT}$ trong tương lai để dự đoán các bệnh viêm não tuỷ rải rác cấp hoặc bệnh xơ cứng rải rác ở các bệnh nhân này

\section{KẾT LUÂAN}

Viêm thị thần kinh ở trẻ em là bệnh lý hiếm gặp, biểu hiện lâm sàng phong phú, thường có thị lực giảm nặng tại thời điểm khởi phát. CHT sọ não - ổ mắt có vai trò quan trọng trong chẩn đoán bệnh cũng như trong quá trình theo dõi bệnh, và góp phần vào việc đưa ra tiên lượng lâu dài cho bệnh nhân.

\section{TÀI LIẸU THAM KHẢO}

1. Gise R.A. and Heidary G. (2020). Update on 
Pediatric Optic Neuritis. Curr Neurol Neurosci Rep, 20(3), 4.

2. Lehman S.S. and Lavrich J.B. (2018). Pediatric optic neuritis. Curr Opin Ophthalmol, 29(5), 419422.

3. Wilejto M., Shroff M., Buncic J.R., et al. (2006). The clinical features, MRI findings, and outcome of optic neuritis in children. Neurology, 67(2), 258-262.

4. Averseng-Peaureaux D., Mizzi M., Colineaux $H_{.}$, et al. (2018). Paediatric optic neuritis: factors leading to unfavourable outcome and relapses. $\mathrm{Br}$ J Ophthalmol, 102(6), 808-813.

5. Lê Thi Doan (2013). Nghiên cứu một số đặc điểm lấm sàng và kết quả điều trị bênh viêm thị thần kinh ở trẻ em tại Bệnh viện Mắt trung ương trong 5 năm (2008-2012).
6. Ambika S., Padmalakshmi K., Venkatraman V., et al. (2018). Visual Outcomes and Clinical Manifestations of Pediatric Optic Neuritis in Indian Population: An Institutional Study. J NeuroOphthalmol Off J North Am Neuro-Ophthalmol Soc, 38(4), 462-465.

7. Absoud M., Cummins C., Desai N., et al. (2011). Childhood optic neuritis clinical features and outcome. Arch Dis Child, 96(9), 860-862.

8. Sri-udomkajorn S. and Pongwatcharaporn K. (2011). Clinical features and outcome of childhood optic neuritis at Queen Sirikit National Institute of Child Health. J Med Assoc Thail Chotmaihet Thangphaet, 94 Suppl 3, S189-194.

9. Yeh E.A., Graves J.S., Benson L.A., et al. (2016). Pediatric optic neuritis. Neurology, 87(9 Suppl 2), S53-58.

\section{KẾT QUẢ ĐIỀU TRI UNG THƯ TRỰC TRÀNG THÁP (T3-4) ĐƯỢC ĐÎ̀U TRI HÓA XẠ TRI BỔ TRỢ TRƯỚC VÀ PHẪU THUÂTT BẢO TỒN CƠ THẤT}

Đỗ Tất Cường ${ }^{1}$, Bùi Vinh Quang ${ }^{1}$, Hoàng Mạnh Thắng², Nịnh Thị Thảo ${ }^{1}$, Nguyễn Hoàng Gia ${ }^{1}$, Võ Quốc Hoàn ${ }^{1}$, Trần Quang Kiên ${ }^{1}$, Nguyễn Hoài Nam ${ }^{1}$, Phạm Anh Đức ${ }^{1}$

\section{TÓM TẮT}

Mục tiêu: Đánh giá kết quả điều trị ung thư trực tràng thấp (T3-4) được hóa xạ trị bổ trợ trước và phẩu thuật bảo tồn cơ thắt. Đối tượng và phương pháp nghiên cứu: Nghiên cứu mô tả cắt ngang trên 44 bệnh nhân ung thư trực tràng giai đoạn T3-4N0-2MO tại Bệnh viện $K$ và Bệnh viện Ung Bướu Hà Nội từ năm 5/2016 đến 5/2021 được hóa xa tri tiền phầu sau đó phẫu thuật bảo tồn cơ thắt. Kết quả: Sau điều trị hóa xa trì, tỷ lê đáp ứng hoàn toàn, đáp ứng một phần, bệnh ôn định lần lượt là $9,1 \%, 52,3 \%$ và $38,6 \%$. Không ghi nhân trường hợp nào bênh tiến triển. Thời gian sổng thêm không bệnh (DFS) trung bình là 45,16 33,51 tháng. Tỷ lê sống thêm không bệnh 1 năm là $97 \%$, tại thời điểm 2 năm là $77,4 \%$, tại thờ điểm 3 năm là $68,3 \%$.Kết luân: Hóa xạ trị bổ trợ trước và phẫu thuâat bảo tồn cơ thắt là phương án điều trị hiệu quả ở nhóm bệnh nhân UTTT thấp giai đoạn tiến triển tai chố.

Tư khóa: Hóa xa trước phẫu thuật, bảo tồn cơ thắt, giai đoạn tiến triển tại chỗ, ung thư trực tràng thấp.

\section{SUMMARY \\ EFFECTIVENESS OF PREOPERATIVE CHEMORADIOTHERAPY AND SPHINCTER PRESERVING SURGERY FOR RECTAL}

\footnotetext{
${ }^{1}$ Bệnh viện Ung Bướu Hà Nội

${ }^{2}$ Bênh viên $K$

Chịu trách nhiệm chính: Đỗ Tất Cường

Email: tatcuong0310@gmail.com

Ngày nhận bài: 30.7.2021

Ngày phản biên khoa họ: 29.9.2021

Ngày duyệt bài: 6.10 .2021
}

\section{CANCER (T3-T4)}

Objective: To evaluate the efficiency of preoperative chemoradiotherapy and sphincterpreserving surgery for patients with locally advanced distal rectal cancer. Patients and methods: Description study of 44 patients with locally advanced distal rectal cancer who had received preoperative chemoradiotherapy and sphincter-preserving surgery between May 2016 and May 2021. Results: According the pathologic examination of rescted specimens in patients who had received neo-adjuvant chemoradiotherapy, complete pathologic response was observed in $9,1 \%, 52,3 \%$ showed near complete pathologic response. The mean disease free survival (DFS) was $45,16 \pm 3,51$ months. DFS rates of 1 year, 2 years and 3 years were respectively $97 \%, 77,4 \%$ and $68,3 \%$. Conclusion: Preoperative chemoradiotherapy and sphincter preserving surgery is the cornerstone and effective treatment in locally advanced distal rectal cancer.

Key words: preoperative chemoradiotherapy, anal sphincter preserving surgery, locally advanced, rectal cancer.

\section{I. ĐẶT VẤN ĐỀ}

Ung thư trực tràng (UTTT) là một trong những bệnh ung thư phổ biến ở nước ta và các nước trền thế giới. Theo ước tính của GLOBOCAN 2018, tại Viêt Nam có 8815 trường hợp mắc mới, với tý suất 5,4/100.000, và 4673 trường hợp tử vong do UTT, với tỷ suất 4,1/100.000[1].

Hiện nay, bệnh nhân UTTT đến khám bệnh ở giai đoạn muộn, nên tỷ lệ các bệnh nhân được điều trị phẫu thuật triệt căn và phẫu thuật bảo 